\title{
How to address Hyperobjects in exhibitions using emerging technologies
}

\author{
Nils Wiberg
}

This paper will show some ways in which the interaction can harmonize with the interpretation and the topic at hand. But it will also tackle the new forms of understanding and interpretation that have emerged in recent years and how they can be translated in to interaction. It outlines the addition of another $\mathrm{O}$ in the discourse: the operative one. Using examples of implementations it shows that together can make palpable these new findings and perspectives to visitors of exhibitions in general and their interpretation of Land in particular.

Keywords: Speculative Realism, Object Oriented Ontology, Philosophy, Exhibition Design, Interpretive Planning, Land Use Interpretation, Emerging Technologies, New Interfaces

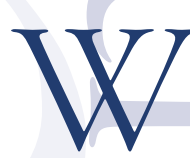

hen designing the interaction for cultural heritage, or any other museal experience it is optimal that before one spatializes the interpretation and divides topics to find an underlying interactive metaphor that holds for the entire experience. That is to say in the same way as the visual aesthetic must go hand in hand with the topic at hand, so must the integration aesthetic.

\section{Explanandum}

For example when we were designing an installation for the sea monster museum in Bíldudalur in the north of Iceland, it was important to tailor the interaction to the complete narrative of the museum. The concept of it was to tell the story of the cryptozoological past of the past of the Icelandic west fjords in a Harry-potteresque kind of time capsules research center for the study of sea monsters. It ought to appear to have been frozen in time at the turn of the 2 oth century and now rediscovered and exhibited as such. The narrative then took place on a sort of meta-level of anthropology.

To place a futuristic or even modern interface in such a context would appear highly anachronistic so what we instead did was to adapt the interaction aesthetic to the mechanistic ideals of the time and just augment those interactions with the power of pixels. When the physical nature of the wheels that moves the map creates a natural form of momentum scrolling that, par-

I Nils Wiberg, Use Qualities: An Organic Luxury We Can Afford. A Primer and Implementation of how Organic Interfaces can Improve the Use Quality Affordance (Umeå: Umeå University, 2009).

2 The results can be seen at http://gagarin.is/work/sea_monster_table. (2016-02-01). 
ticularly map, interfaces otherwise try to mimic in a kind skeuomorphism of interaction, the pretention of physicality. Physical pucks were chosen as the interactive elements for the table top rather than a touch screen interface, with to retain the physical, tangible aesthetic and to so to speak, to outsource complexity to the physical world. Two pucks can for example not be at the sample place at the same time thus the social interaction of people solves any potential problem of two people competing for the same content. A similar solution as we have seen in our different interactions of a Wheel of Time. ${ }^{3}$

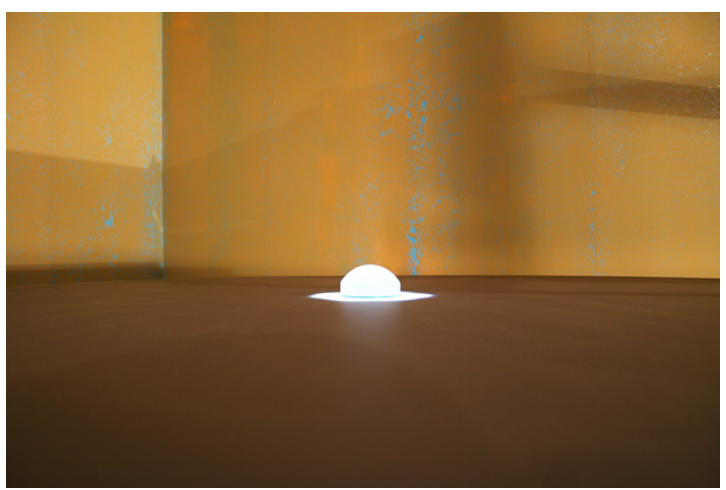

Similarly when we were asked to explain the concepts surrounding electricity in an exhibitory form we chose the starting point of the power within people. With a first installation consorting of a semi transparent concrete wall visitors were asked to exude pressure on the wall which had a large screen embedded in it. The visual result communicated, or primed, this as the informing metaphor ${ }^{4}$ of the exhibition. Now it was easy to further explain the other forms of energy through the exertion of power in the visitor translated in the different kinds and translations of power, work, energy and electricity. Then the visitor is free to move, lift and pump the information out of the exhibits. ${ }^{5}$

In creating a metaphor for the recent exhibition for the town in the Westman islands

https://vimeo.com/153748339 (2016-02-o1).

4 Lakoff, George and Mark Johnson, Metaphors We Live By (Chicago: University of Chicago Press, 1980).

5 Gagarin, "Powering the Future", http://gagarin.is/work/powering_the_future (2016-02-0I)

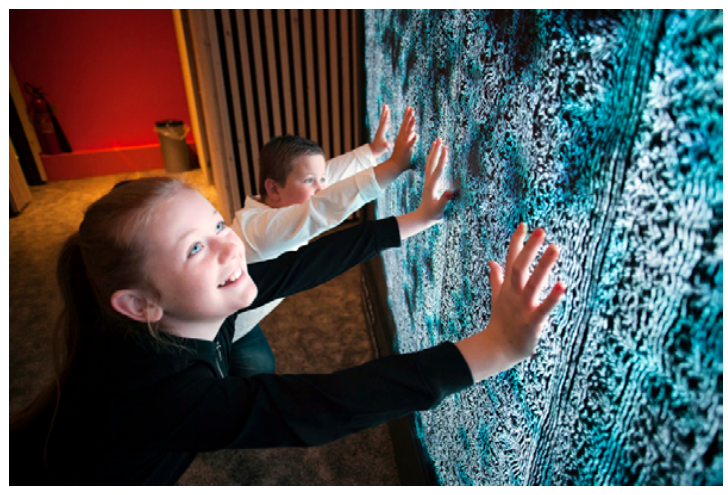

of Iceland that suffered a volcano eruption we choose to use again physical metaphors but here ones where the users act as first responders and excavators, using the camera to search in houses too dangerous to enter, pushing together the ruined houses to see them in their original condition and fittingly an interactive sandbox where visitors dig in actual sand from volcano ash to reveal digital content about the things hidden under the lava in this Pompeii Of the North.

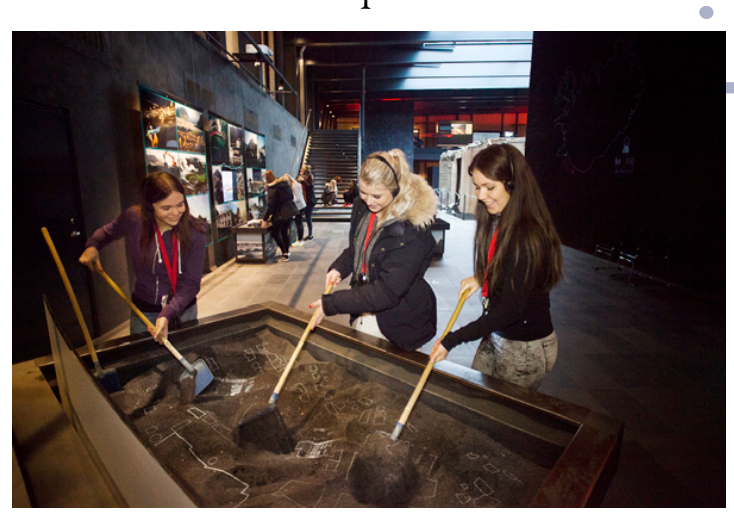

When creating these metaphors the aesthetic integrity of the interaction is completely integral to the outcome. Retaining the visitor's belief in the interaction is what keeps estrangement at bay and focuses on the story you want to tell. This is why quality is important. The appearance of latency etc. has to be without failure. It's a magic trick and magic tricks don't work if you make MOST of the bunny rabbit disappear, all your left with then are crying children.

6 Gagarin, „Eldhemar“, http://gagarin.is/work/eldheimar (2015-02oI). 
This for example was very important when creating the interaction for our National Park Explorer ${ }^{7}$ in a national park in Breheimen Norway. Here the feedback of the physical interaction was not on the object itself but rather on the map all user interact with, therefore we were unable to make latency a playability feature, which we had previously done in the aforementioned sea monster table, where the latency was incorporated as a use quality contributing to the lurking feeling of vulnerability we wanted the visitors to experience. Since the control function and the feedback were separated in the National Park Explorer however the latency had to be kept at a minimum to keep the mental pairing of the input and the feedback intact.

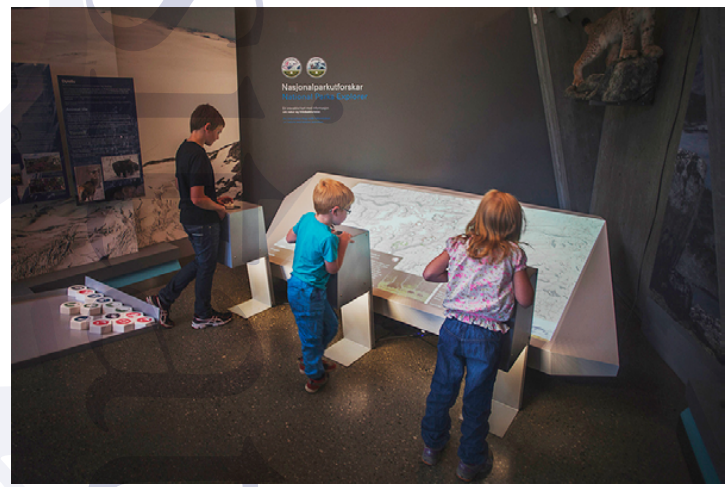

Based on these example we see that it is completely possible to incorporate the interaction as a part of the interpretation and interaction. However in a few of our upcoming projects there is a new class of issues more and more prevalent in museums that require a new class of interactive approaches.

\section{Theoretical background}

In recent times some headway in the philosophical approach of the most pressing issues of our time have been made. Due to a philosophical standstill over the last roo years, few scientists, artists or designers have looked to philosophy to find answers or even questions. The ones who did oftentimes found themselves in a Heideggerian maze of circular arguments. The problem

Vimeo, https://vimeo.com/72203926 (20016-02-OI). philosophy faced was that of not finding enough terra firma to stand on in order to basically say anything about reality itself. There has been, since Kant, and some unfortunate misinterpretations of Nietzsche, a tending towards an ontological detente where philosophy narrowed its foci of attention. The latter rendered a total value relative argumentation and the former a epistemological recursion. To paraphrase, it could go something like: How can I know that there are (or are not) real things? What gives me (or denies me) access to those real things? What are the possibilities of this access? What is the possibility of possibility? The Kantian rift had become a chasm deep enough to fill almost all of continental philosophy. This correlationism ${ }^{8}$ is not providing answers, or questions, that move or benefit other sciences, art forms or practices. Some philosophers understandably had enough of this and thought about the current issues facing humanity, e.g. technological singularity; machine-human mergers or global warming.'

\section{Background}

The shortcomings of the academic paper mill might be to blame here. These thoughts have predictably not evolved through the academic circuit as intended, but instead been circulating on forums on the internets where people within academia who have been frustrated with the existing forms of academic output and its incapability to accommodate new, unfinished, thoughts or work in progress.

The discourse has sort of ventured all the way into a place where one has been forced to ask oneself: Why save a species if one does not believe in a species. Particularly this needs to have an operational level as well. That something can be done even though we do not agree on holistic definitions or hierarchies or what privileges whom.

Of all the things humans have created, releasing the hyper object of climate change will

8 Levi Bryant, Nick Srnicek and Graham Harman, ed.The speculative turn (Melbourne, [Victoria] Australia: re.press, 201 I).

9 Timothy Morton, Hyperobjects: Philosophy and Ecology after the End of the World (Minneapolis: University of Minnesota Press, 2013). 
probably be our last legacy. A battle for humanity's remaining legacy will exist between the pyramids of Giza and the traces of the 1986 Chernobyl disaster from which newly born lichen of the Norwegian highlands in the autumn of its life span will still contain traces of cesium.

Culture as such could maybe be counted from the cave paintings and onwards. When looking at the oldest paintings from about 30 ○o years ago and extrapolated equally far into the future, maybe the only trace of humanity would be its vain attempts of terraforming and contribution to climate change. If we were to stop releasing carbon now, $25 \%$ of it will still be in affect 30000 years out.

There is however within the fields of speculative realism and object oriented ontology a movement towards dealing with this problem. A realization has been reached by continental philosophers; beyond internal debates of monism/ dualism etc; that intellectual headway need making. And a strategy for how said headway can be made has been laid out.

\section{0}

In classic style of continental philosophy however there seems to be lacking a niveau of implementation to this theoretical strategy. Lets call it a tactical or operative level. This is where this paper is suggesting a number of very specific examples of how such implementation can be done. In terms of how the implementation is intended it is a kind of operationalization of speculative realist thought and object oriented ontological classes. So what then would be the outcome? It could be actual things that occupy the world in a more non-deceptive way. Cellphones that contain visual or aesthetic traces from the nickel mines that make them possible. It could be sneakers whose transparency reflect not its technical material qualities but instead the burdens of the underlying working conditions that are its prerequisites. A moral transparency rather then a material one so to speak.

However one would also have to go further in order to fully allow for these ideas to be able to be instituted in objects. They should not only be result on ontological levels of say consumer products but also on an epistemological level. This thus brings us to the didactic tools which are used to create knowledge. These have evolved tremendously in recent years and become much more participatory, interactive and containing certain feedback loops and distribution of power (Wikipedia comes to mind). But they, the tools of learning, are in practice quite opaque in this sense. They require a lot from an informed user and do not, as of yet, in any aestethic or visual way communicate their bias. Lets take for example a geographical information system. It has a lot of embedded value based or political choices; however these are not immediately visual to the user.

\section{OOOOI}

As an object of examination a few implementations on an operative level will show the attempts to try and enable a polysemy of sorts in term of how the design and interpretation of geography/ geology and land can be designed.

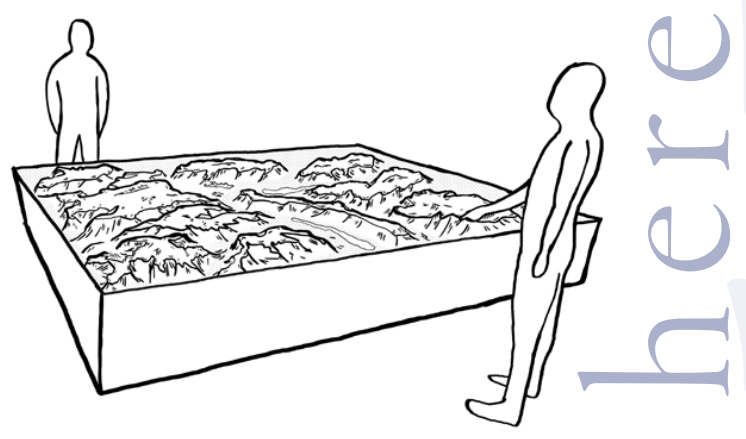

The design objects we firstly use as examples is a $3 \mathrm{~d}$ map interface that contains two viewing perspectives, each from different floor levels and with different interactions but both using the same object (map) as feedback. This dual view would afford on the one hand a utilitarian perspective on what this land can be used for, in a tourist way rather than a land use interpretation 
way; on the other hand it shows how this land (and its utilities) are being threatened from the second floor.

The effect sought here would be that since the focus of attention remains the same, a map, but the perspectives are different, utility/climate(threat posed to utility), a more broad and differentiated didactic can be achieved. One can

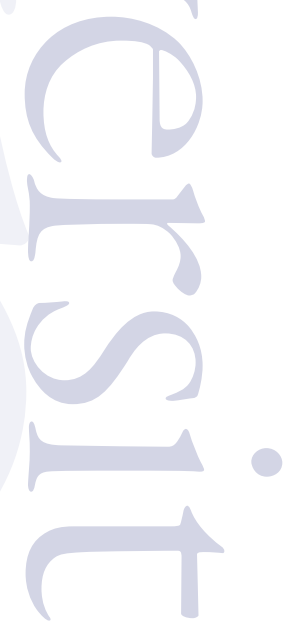

on the one hand inform on what kind of activities that are available and at the same time, from the second level see how those same activities are

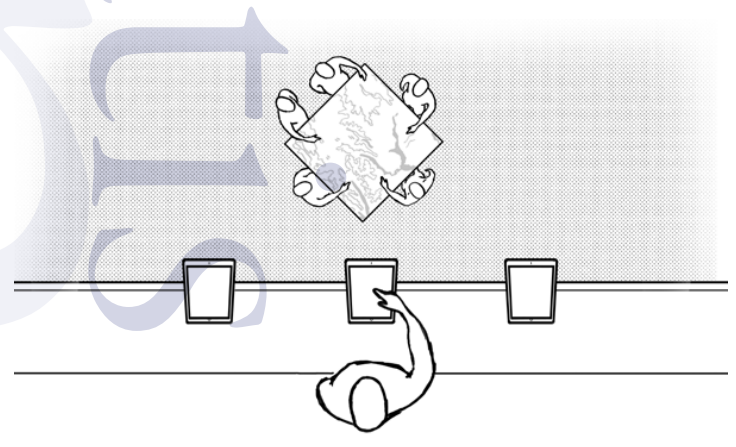

being threatened from a changing climate. For example one can in the first level get to examine where there are summer houses for rent and then on the second level see how those summer house are under threat from rising sea levels. These two levels then work in tandem, they only have meaning in tandem and are dramaturgical contingent on each other. One might be of the per- suasion that the latter perspective is somehow "truer" and the first one more real but these are both needed to complete, an albeit incomplete picture. One doesn't know what is being threatened without the utility and one doesn't know what is the threat without the zoomed out climatological view.

In a third installation the Land Interpreta-

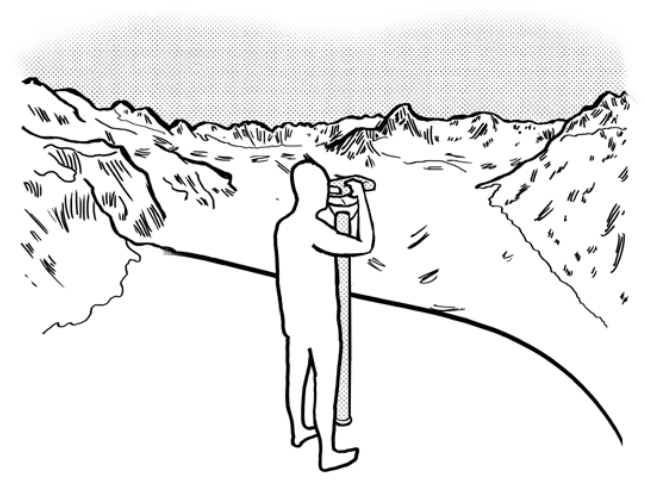

tion becomes very vivid and palpable: with the use of augmented reality binoculars one can create layers of information put on top of existing landscape in real time. As a result the geological time perspective can be viewed in a sped up manner. For example the creation of a fjord as a result of the interaction of a glacier and a mounted can be visualized in ${ }_{3} \mathrm{D}$ and shown as an animation on top of existing vistas. But also the extrapolation in climatology can be brought to this visual medium to show glaciers receding, tree line climbing and water levels rising. All in the very real and tangible way all of the science say is necessary to get people to not only think on the geological scale but also feel on the geological scale.

These implementations can more accurately represent, in a compelling interaction and participatory way these new hyper objects. The dual (or plural) layers of objects can be reveal through user interactions from different points of view. Imagine for example a deictic interaction that takes in to account the point of view from which the spectator is pointing to reveal the content 
information interactively from specifically that point of view. These kinds of interactive and participatory way of content dissemination has totally new possibilities to cater to the more complex issues of our time.

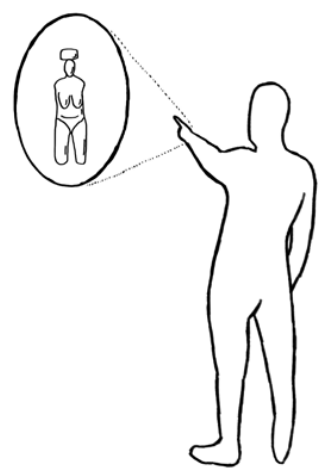

\section{Povzetek}

Pri oblikovanju in pripravi interpretativnega načrta za interaktivne razstave je pomembno razmišljati o tem, katere interaktivne metafore uporabiti. Če namreč interaktivnost ni pravilno uporabljena, lahko ovira razumevanje interpretacije namesto da ga podpira. Članek je pokazal nekaj načinov, s katerimi se lahko interakcijo uskladi z interpretacijo teme, poleg tega pa se je dotaknil tudi novih oblik razumevanja in razlage, ki so se pojavile v zadnjih letih in kako jih je mogoče prevesti v interakcijo. $V$ zadnjih letih sta špekulativni realizem in objektno usmerjena ontologija ustvarila take paradigme v filozofiji, da so skušale opusti idealistični razkol ter omogočiti, da se ukvarjajo s perečimi vprašanji v današnjem času. Ta dokument opisuje dodajanje drugega O-ja v diskurzu, in sicer tistega operativnega. $Z$ uporabo primerov implementacije se dokazuje te nove ugotovitve in možnosti za obiskovalce razstav na splošno in njihovo interpretacijo dežele še posebej. Rezultat cilja predvsem k temu, da se omogoči premike žarišč, hkrati pa ohranja predmet pozornosti za muzejske obiskovalce.

\section{Summary}

When designing and doing interpretive planning for interactive exhibitions it is important to think of what interactive metaphors to employ. If not used correctly the interactivity can impede understanding of the interpretation instead of supporting it. This paper has shown some ways in which the interaction can harmonize with the interpretation and the topic at hand. But it has also tackled the new forms of understanding and interpretation that have emerged in recent years and how they can be translated in to interaction. In recent years speculative realism and object oriented ontology have created a paradigm shift of sorts in philosophy in order to leave behind the idealist rift and enable it to deal with the pressing issues of our modern times. This paper outlines the addition of another $\mathrm{O}$ in the discourse: the operative one. Using examples of implementations that together can make palpable these new findings and perspectives to visitors of exhibitions in general and their interpretation of Land in particular. The resulting designs aim to enable shifts of foci whilst retaining the object of attention for the museum visitor.

\section{References}

Lakoff George and Mark Johnson, Metaphors We Live By (Chicago:University of Chicago Press, 1980).

Bryant Levi, Nick Srnicek and Graham Harman, ed.The speculative turn (Melbourne, [Victoria] Australia: re.press, 2011).

Morton, Timothy, Hyperobjects: Philosophy and Ecology after the End of the World (Minnesota: University of Minnesota Press, 2013).

Nils Wiberg, Use Qualities: An Organic Luxury We Can Afford. A Primer and Implementation of how Organic Interfaces can Improve the Use Quality Affordance (Umeå: Umeå University, 2009).

Gagarin, "Eldheimar" http://gagarin.is/work/ eldheimar (2015-02-OI).

Gagarin, "Sea Monster", http://gagarin.is/ work/sea_monster_table (2015-02-OI).

Vimeo(a), https://vimeo.com/153748339 (2015O2-OI).

Vimeo(b), https://vimeo.com/72203926 (2015O2-OI).

\title{
(T)
}

1

$\checkmark$

$d$

$-$

O

\section{(}

(1)

\section{A}

